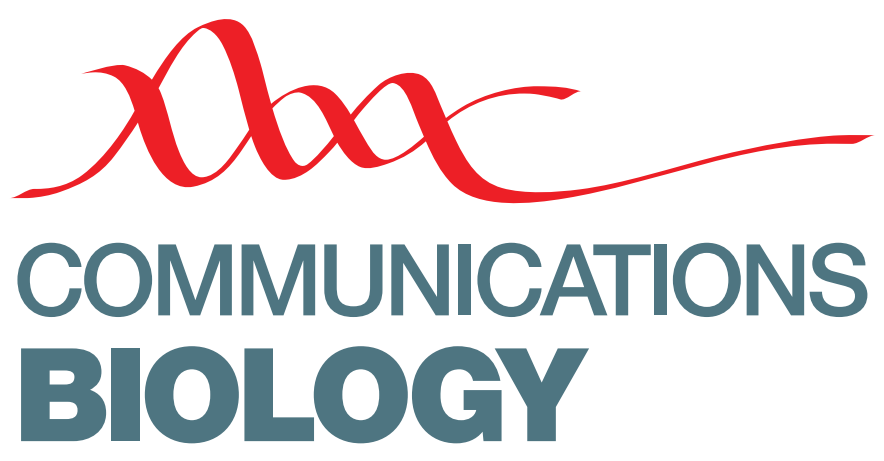

Check for updates

https://doi.org/10.1038/s42003-020-01291-8 OPEN

\title{
Author Correction: Genetic alterations in the 3q26.31-32 locus confer an aggressive prostate cancer phenotype
}

\author{
Benjamin S. Simpson (1), Niedzica Camacho, Hayley J. Luxton (1D, Hayley Pye (1D, Ron Finn, Susan Heavey (D), \\ Jason Pitt, Caroline M. Moore \& Hayley C. Whitaker (1)
}

Correction to: Communications Biology https://doi.org/10.1038/s42003-020-01175-x, published online 14 August 2020.

In the original version of the published Article, the following affiliation was incorrectly included for author Niedzica Camacho: "Department of Pathology, Memorial Sloan Kettering Cancer Center, New York, New York for Genomics Research, Discovery Sciences, Biopharmaceutical R\&D, AstraZeneca, Cambridge, UK”. This affiliation has been removed in the PDF and HTML versions of the Article.

Published online: 08 October 2020

\footnotetext{
(c) (i) Open Access This article is licensed under a Creative Commons Attribution 4.0 International License, which permits use, sharing, adaptation, distribution and reproduction in any medium or format, as long as you give appropriate credit to the original author(s) and the source, provide a link to the Creative Commons license, and indicate if changes were made. The images or other third party material in this article are included in the article's Creative Commons license, unless indicated otherwise in a credit line to the material. If material is not included in the article's Creative Commons license and your intended use is not permitted by statutory regulation or exceeds the permitted use, you will need to obtain permission directly from the copyright holder. To view a copy of this license, visit http://creativecommons.org/licenses/by/4.0/.
}

(C) The Author(s) 2020 